\title{
DAS RUAS PARA OS CURRÍCULOS: PRECURSORES SOCIAIS E JURÍDICOS DAS LEIS 10.639/03 E 11.645/08
}

\author{
ANA PAULA DOS SANTOS DE SÁ ${ }^{1 *}$ \\ ORCID: https://orcid.org/0000-0001-8967-8595
}

\begin{abstract}
RESUMO: O objetivo deste artigo é investigar os percursos sociais e jurídicos das leis federais brasileiras $\mathrm{n}^{\mathrm{o}}$ 10.639/03 e n $\mathrm{n}^{\mathrm{o}}$ 11.645/08 - que tornaram obrigatório o ensino de conteúdos referentes à História e à Cultura afro-brasileira e indígena brasileira em toda a educação básica -, com base na premissa de que políticas dessa natureza alinham-se a um processo de descolonização do sistema educacional. Para tanto, revisamos, comparativamente, discursos e ações da militância negra e indígena no campo da educação, de modo a compreender as motivações e os eventos que antecederam a promulgação de ambas as leis. Nossas conclusões apontam que, a despeito das particularidades das demandas de cada militância - haja vista os esforços do movimento indígena para se desvencilhar da educação ofertada pelo sistema oficial de ensino, enquanto que a população negra, ao contrário, lutava para ter acesso igualitário a esse mesmo sistema -, as duas medidas resultam, em maior ou menor grau, de denúncias e de questionamentos acerca da matriz e/ou do legado colonial que marca, historicamente, os currículos e as escolas brasileiras.
\end{abstract}

Palavras-chave: Lei 10.639/03; Lei 11.645/08; Movimento Negro; Movimento Indígena; Multiculturalismo.

\section{FROM THE STREETS TO CURRICULA: SOCIAL AND LEGAL PRECURSORS OF LAWS 10,639/03 AND $11,645 / 08$}

\begin{abstract}
The objective of this article is to investigate the social and legal paths of the Brazilian federal laws $\mathrm{n}^{\circ} 10.639 / 03$ and $\mathrm{n}^{\circ} 11.645 / 08$ - which made mandatory the teaching of content related to Afro-Brazilian and Indigenous Brazilian History and Culture in all basic education - based on the premise that policies of this nature are aligned with a process of decolonization of the educational system. To this end, we comparatively reviewed the discourses and actions of black and indigenous militancy in the field of education in order to understand the motivations and events that preceded the enactment of both laws. Our conclusions point out that, despite the particularities of the demands of each militancy - as seen in the efforts of the indigenous movement to disentangle itself from the education offered by the official school system, while the black population, on the contrary, fought to have equal access to this same system - both measures result, to a greater or lesser extent, from denunciations and questionings about the colonial matrix and/or legacy that historically marks Brazilian curricula and schools.
\end{abstract}

Keywords: Law 10.639/03; Law 11.645/08; Black Movement; Indigenous Movement; Multiculturalism.

1 Departamento de Educação (DEd) da Universidade Federal de São Carlos (UFSCar). São Carlos, SP, Brasil. <anapss.unicamp@gmail.com>.

* O presente trabalho origina-se da tese de doutorado defendida pela autora (DE SÁ, 2019) e foi realizado com apoio da Coordenação de Aperfeiçoamento de Pessoal de Nível Superior - CAPES (processo no 88887.474608/2020-00) e do Conselho Nacional de Desenvolvimento Científico e Tecnológico - CNPq (processo n.o 140725/2015-6). 


\section{DE LAS CALLES A LOS CURRÍCULOS: PRECURSORES SOCIALES Y JURÍDICOS DE LAS LEYES $10.639 / 03$ Y 11.645/08}

RESÚMEN: El objetivo de este artículo es investigar los caminos sociales y legales de las leyes federales brasileñas $n^{\circ} 10.639 / 03$ y n $n^{\circ} 11.645 / 08$ - que hicieron obligatoria la enseñanza de contenidos relacionados con la Historia y la Cultura Afrobrasileña e Indígena Brasileña en toda la educación básica -, partiendo de la premisa de que tales políticas están alineadas con un proceso de descolonización del sistema educativo. Hemos revisado comparativamente los discursos y acciones de la militancia negra e indígena en el campo de la educación para comprender las motivaciones y los eventos que precedieron a la promulgación de ambas leyes. Nuestras conclusiones señalan que, a pesar de las particularidades de las demandas de cada militancia - ya que el movimiento indígena se esforzaba por deshacerse de la educación ofrecida por el sistema educativo oficial, mientras que la población negra, por otro lado, luchaba por tener un acceso igualitario a este sistema -, las dos medidas resultan, en mayor o menor medida, de las denuncias y cuestionamientos sobre la matriz y/o el legado colonial que marca históricamente los planes de estudio y las escuelas brasileñas.

Palabras clave: Ley 10.639/03; Ley 11.645/08; Movimiento Negro; Movimiento Indígena; Multiculturalismo. 


\section{INTRODUÇÃO}

A lei federal brasileira no 10.639/2003 alterou a Lei de Diretrizes e Bases da Educação Nacional (LDBEN) da educação básica, a saber, lei no 9.394/1996, ao tornar obrigatório o ensino sobre História e Cultura Afro-Brasileira. Atualizada anos depois pela lei $n^{\circ} 11.645 / 2008$, a medida passa a abranger também os conteúdos sobre a História e a Cultura dos povos indígenas brasileiros. Na prática, a nova legislação força uma revisão do repertório escolar (a nível dos currículos, dos livros didáticos etc.), uma vez que determina que negros e indígenas sejam abordados como sujeitos do discurso e produtores de arte e de conhecimento, e não apenas como personagens de narrativas de matriz eurocêntrica.

Ao encontro de Pereira (2011), em sua análise sobre o papel do movimento negro no tocante à primeira lei, questionamos, de início, a ideia de que leis dessa natureza surjam "de repente, de cima para baixo", como uma mera "imposição do governo aos professores" (PEREIRA, 2011, p. 25). Ao contrário, elas refletem um conjunto de lutas históricas da sociedade civil, evidenciando a contribuição dos movimentos sociais no campo do saber, bem como os protagonismos por eles assumidos na história da educação do país. Sob esse prisma, é correto afirmar, por sua vez, que a reivindicação e o reconhecimento da pluralidade cultural nas escolas, ideologia denominada, com frequência, de "multiculturalismo", "não surgiu como um movimento no campo da educação", mas "invadiu" a esfera educacional "porque minorias, não em números, mas em poder e influência, há muito reivindicavam o cumprimento dos princípios de igualdade e equidade, relativos às constituições de todos os países democráticos" (GONÇALVES \& SILVA, 2003, p. 111).

Estabelecendo certa proximidade, portanto, com o teor de revisões históricas como a já desenvolvida por Pereira (2011), este artigo visa investigar os percursos sociais e jurídicos de ambas as leis, de modo a compreender os eventos, as ações e os discursos que possibilitaram essas conquistas na esfera legal. A escolha por dar atenção tanto à militância indígena quanto à militância negra deve-se ao fato de considerarmos produtiva a verificação de eventuais discrepâncias e/ou similaridades nesses processos, haja vista este estudo partir da premissa de que, a despeito de eventuais especificidades, leis como a 10.639/2003 e a 11.645/2008 têm em comum o questionamento e o enfrentamento da matriz e/ou do legado colonial que embasa, historicamente, os currículos e as escolas brasileiras.

À luz dos aportes teóricos dos Estudos Pós-Coloniais, admitimos que a independência geográfica e política conquistada por ex-colônias não é sinônimo, necessariamente, de independência cultural e simbólica (HALL, 2003). Isso porque a dominação territorial é também sustentada por uma dominação ideológica, ou seja, pela imposição de valores e de visões de mundo, a qual deixa um legado tão ou mais difícil de se enfrentar. No caso do Brasil, em particular, seria precipitado associar, pois, o 7 de setembro de 1822 a uma independência também dos modos de pensar, sobretudo ao se ter em vista que a história da educação brasileira é a história de um sistema de ensino criado por e para uma elite econômica, composta, inicialmente, pelos colonos europeus e seus descendentes.

Nota-se, assim, uma trajetória educacional que acaba por demandar um olhar pedagógico alinhado àquilo que Gomes (2017), inspirada pelas teorias de Boaventura de Sousa Santos, denomina de "pedagogia das ausências e das emergências", ou seja, um olhar que reconheça, por um lado, a "produção de não existência" de determinados saberes na esfera escolar - em específico, os saberes dos grupos não hegemônicos e contra-hegemônicos - , e que, por outro, instaure um inconformismo ante a tais lacunas, assim como expectativas de que estas sejam superadas através da abertura a um campo de possibilidades concretas de novos saberes (p. 40-43). Destarte, nossa premissa de que a educação brasileira situa-se, ainda hoje, num contexto pós-colonial - sendo o "pós-colonial" não um marco temporal específico de superação do domínio europeu, mas, ao contrário, um contexto em que perduram, em maior ou menor grau, os efeitos da dominação colonial - prevê, justamente, um cenário de constante tensões entre a presença de heranças coloniais e o enfrentamento e a negação desse legado, no qual leis de recorte multicultural assumem um relevante papel, principalmente na esfera escolar.

Nas próximas seções, revisamos, então, o duplo papel exercido pelos movimentos indígena e negro no que tange à acusação de "ausências" e à demanda por "emergências" no campo da educação. Posteriormente, a título de comparação dos dois quadros, recorremos aos subsídios da pensadora Nancy Fraser sobre as especificidades das políticas de combate a injustiças sociais, a fim de refletirmos sobre os pontos convergentes e divergentes das ações orquestradas pelos dois grupos. 


\section{DAS RUAS PARA OS CURRÍCULOS}

\section{Precursores sociais e jurídicos da lei $\mathrm{n}^{\circ} 10.639 / 2003$}

A lei 10.639, de 9 de Janeiro de 2003, tem origem no Projeto de Lei (PL) 259/1999, de autoria de Esther Grossi (PT/RS) e Ben-hur Ferreira (PT/MS), cujo texto-base cita o parlamentar Humberto Costa (PT/PE) como seu propositor inicial, bem como destaca, entre outros aspectos, a necessidade de "desmistificar o eurocentrismo" e o fato de "a sociedade dominante" discriminar e inferiorizar os negros "em relação ao chamado SABER UNIVERSAL" ("Projeto de Lei (PL) 259/1999" apud DA CONCEIÇÃO, 2011, pp. 108-110). Contudo, embora tal Projeto assuma oficialmente o posto de antecessor jurídico da lei de 2003, cabe frisar que se trata do último, mas não do único PL associado ao tema. Sabe-se atualmente que muitos parlamentares, para além de Costa, apresentaram propostas afins no decorrer das décadas de 1980 e 1990. A menção exclusiva ao deputado se deve, nesse caso, ao fato de a justificativa do PL 259/1999 basear-se, quase que totalmente, no texto que fundamentou tanto o PL 948/93, apresentado por Costa à Assembleia Estadual de Pernambuco, quanto o PL 859/95, por ele submetido, em um segundo momento, à Câmara dos Deputados, sendo ambos voltados à obrigatoriedade das disciplinas de História e de Cultura Afro-brasileira (PL 948/93 e PL 859/95 apud DA CONCEIÇÃO, 2011, pp. 91-94 e pp. 104-106 [vide “Anexo B” e “Anexo F”]).

A partir de revisões historiográficas como as realizadas por Da Conceição (2011), sabe-se hoje que se soma às ações supracitadas um número significativo de proposições afins que antecederam a lei de 2003: PL 678/88, de Paulo Paim (PT/RS), com foco nas disciplinas de "História Geral da África e História do Negro no Brasil”, em toda a rede pública e privada; PL do Senado 18/95, de Benedita da Silva (PT/RJ), centrada na reivindicação da "História e Cultura da África" na educação básica e superior; e PL do Senado 75/97, de Abdias do Nascimento (PDT/RJ), que remete a um projeto de "ações compensatórias" (PL 1332/1983) por ele apresentado na Câmara dos Deputados em 1983 e arquivado em 1989, sem ter chegado à votação final para aprovação ou rejeição². Sobre este, verifica-se no texto da proposta inicial de 1983, disponível na página oficial do autor do projeto ${ }^{3}$, a sugestão de medidas educacionais bastante próximas daquilo que vieram a ser as orientações regulatórias da lei 10.639/2003, tais como a necessidade de revisão de materiais didáticos e o incentivo da abordagem do tema por parte das universidades ${ }^{4}$.

Ações similares também podem ser encontradas a nível regional, dado que, ainda na década de 1980, ocorriam, por exemplo, a implantação de disciplinas sobre as culturas afro-brasileira e africanas em Salvador (BA) e a implementação de um projeto municipal sobre cultura negra na cidade do Rio Janeiro (PINTO, 1987). Nota-se, portanto, que, seja a nível municipal, estadual ou federal, vem de longa data, no âmbito legislativo, a luta pela inclusão de temáticas relacionadas à cultura negra e ao continente africano na educação básica brasileira, luta esta que, como é de se esperar, reflete os diversos esforços que vinham sendo empregados pelas militâncias fora dos espaços oficiais de reivindicação. Interessanos, assim, abordar, de forma breve, alguns casos que evidenciem o papel exercido pelas demandas e pelos discursos advindos das ruas nesse processo de descolonização da educação no Brasil.

A exemplo dos diferentes momentos e objetivos que marcaram as ações do movimento negro no século XX, também as medidas, formais e informais, relativas à luta pela educação da população negra revelam suas especificidades no decorrer do tempo. Assim, a preocupação com a alteração dos currículos escolares, percebida nos documentos legais supracitados, não figura como primeira preocupação descolonial do grupo no campo da educação, pois, antes de postular a necessidade de descolonização dos conteúdos escolares, fora preciso agir em prol da descolonização dos portões e dos

\footnotetext{
2 Relatos dos "bastidores" da submissão desses e de outros projetos de lei que antecederam a lei 10.639/03 podem ser consultados em Alberti \& Pereira (2007, pp. 427-439).

${ }^{3}$ Disponível em < http://www.abdias.com.br/atuacao parlamentar/deputado lei.htm $>$. Acesso em <19/11/2018>.

${ }^{4}$ Não foi possível localizar, na íntegra, os textos que fundamentam o PL do Senado 75/97, de modo que consideramos produtivo dar atenção ao PL anterior e de mesmo teor submetido à Câmara dos Deputados em 1983.
} 
muros das escolas, que mesmo no pós-abolição mantiveram a função de barrar a entrada de afrodescendentes.

Não é por acaso que a Imprensa Negra, por exemplo, devido ao seu protagonismo naquele que é entendido como o primeiro estágio do movimento negro brasileiro do século XX - a saber, as décadas de 1920 e de 1930 (PEREIRA, 2008) - discutia e denunciava, com certa recorrência, os problemas educacionais enfrentados pela população negra à época. São ilustrativos, nesse sentido, os excertos compilados por Balsalobre (2009), que, entre outros aspectos (sobretudo linguísticos), se voltam à análise do caráter instrutivo dos periódicos paulistas. Neles, eram relativamente frequentes menções ao analfabetismo dos negros (vide, por exemplo, O Alfinete. Ano I, número 3. Setembro de 1918. apud BALSALOBRE, 2009, p. 21) e à necessidade de união para se combater tal problema (vide, por exemplo, O Clarim d Alvorada. Ano I, número 6. Julho de 1928. apud BALSALOBRE, 2009, p. 25), assim como ao papel a ser exercido pelas famílias negras nesse contexto. Separamos um exemplo:

\author{
Educação \\ Educação corresponde a um conjunto de princípios de ordem social, em que impera a \\ delicadeza, a gentileza, a civilidade. (...) Assim, saibam as mães dirigir seus filhos: ensinem-lhes \\ o caminho do Bem e da Justiça: Dêm-lhes exemplos salutares e, estamos certos, amanhan tereis \\ o homem de côr, a nova geração de que necessitaes! \\ O exemplo dos Paes é a maior força que afecta o espirito da criança. (O Clarim d Alvorada. Ano \\ I, número 5. Junho de 1928. apud BALSALOBRE, 2009, p. 27).
}

Consideramos relevante esse excerto do jornal O Clarim $d$ Alvorada à medida que se tem nele a síntese de um importante aspecto da militância pela educação do negro no início do século XX: tratase de um momento em que a questão da exclusão do sistema oficial de ensino é entendida como algo a ser resolvido, sobretudo, pelos negros, e não, ainda, pelo Estado, seja pela acentuada marginalização sofrida pelo grupo, seja pela impossibilidade de se aproximar dos poderes públicos naquele período. Nesse sentido,

\begin{abstract}
Não há quase referência [no início do século XX] quanto à educação como um dever do Estado e direito das famílias. As entidades invertem a questão. A educação aparece como uma obrigação da família. A crítica ao descaso do governo para com a educação dos negros aparece na mesma proporção em que o protesto racial endurece, ou seja, se radicaliza. (GONÇALVES \& SILVA, 2000, p. 143).
\end{abstract}

Destarte, o tom assumido pela Imprensa Negra, tal qual ilustrado no excerto de O Clarim, evidencia que "o abandono a que foi relegada a população negra motivou os movimentos negros, do início do século, a chamar para si a tarefa de educar e escolarizar as suas crianças, os seus jovens e, de um modo geral, os adultos" (GONÇALVES \& SILVA, 2000, pp. 142-143), uma hipótese reforçada por diversas ocorrências de educação popular/informal observadas nesse ínterim. Sobre elas, ganham destaque as instituições escolares das organizações negras, uma vez que "por intermédio dos jornais negros da época, têm-se informações importantes quanto à existência de escolas mantidas exclusivamente pelas entidades negras, sem qualquer subvenção do Estado" (GONÇALVES \& SILVA, 2000, p. 141). Nas décadas de 1920 e de 1930, é possível citar, por exemplo, o protagonismo das escolas do Centro Cívico Palmares e da Frente Negra Brasileira, na cidade de São Paulo (SP); já na década de 1940, na cidade do Rio de Janeiro (RJ), verificam-se as atividades de educação popular do Teatro Experimental do Negro (TEN), fundado por Abdias Nascimento em 1944 e situado nas dependências da sede da União Nacional dos Estudantes (UNE)5. A partir de investigações da área (vide ROMÃO [2005] e DOMINGUES [2008]), sabe-se que essas entidades ofertavam diversas disciplinas (artes, inglês, história etc.) e consistentes cursos de alfabetização.

Segundo Gonçalves \& Silva (2000), essas ações populares e independentes de escolarização continuam a assumir importante papel social até as décadas de 1970 e 1980, quando há um significativo alargamento da dita "educação comunitária" entre essas organizações, bem como uma intensificação dos

\footnotetext{
${ }^{5}$ Somam-se a esses casos instituições sediadas fora das capitais, como as escolas do Clube Recreativo 28 de Setembro, em Jundiaí-SP, e do Centro Cívico José do Patrocínio, de São Carlos-SP (DOMINGUES, 2008, p. 530).
} 
discursos que questionam as escolas convencionais, sobretudo no que diz respeito ao ensino de História. Acerca desta demanda em especial, Pereira (2011) recorda, por exemplo, a "Carta de Princípios", de 1978, do Movimento Negro Unificado (MNU), escrita logo após a criação da entidade, documento em que se reivindica "entre outras coisas, a reavaliação do papel do negro na história do Brasil e a valorização da cultura negra" (PEREIRA, 2011, p. 26).

Em revisão bibliográfica pioneira sobre a história da educação do negro, Pinto (1987, p. 30) aponta a chamada "Pedagogia Interétnica", de 1978, como a iniciativa de "maior alcance" e de "resultados concretos" nesse viés. Formulada pelo Departamento de Ciências Sociais do Núcleo Cultural AfroBrasileiro (BA) em conjunto com a Universidade Federal da Bahia (UFBA), por meio de pesquisa coordenada pelos sociólogos Roberto Santos e Manoel de Almeida Cruz, seu objetivo era "resgatar os valores afro-brasileiros através da educação formal" (PINTO, 1987, p. 30). Segundo a autora, a medida exerceu influência direta nas mudanças curriculares ocorridas em 1985 na rede estadual da Bahia, a qual incorporou, de forma experimental, a disciplina "Estudos Africanos" nos cursos do $1^{\circ}$ e do $2^{\circ}$ graus.

Ainda nesse período, constata-se também que o movimento negro não esperou pela criação e pela aprovação da lei 10.639/2003 para renovar os materiais didáticos, haja vista a produção de cartilhas independentes ter sido, na altura, "uma prática recorrente nas organizações negras de norte a sul do Brasil” (PEREIRA, 2011, p. 42). Exemplo disso está numa ação ocorrida no estado do Maranhão por intermédio da militante Maria Raimunda Araujo (Mundinha), presidente do Centro de Cultura Negra do Maranhão (CCN), que produziu, em parceria com outros militantes maranhenses, cartilhas que chegaram a ser publicadas, inclusivamente, em outros estados, como Minas Gerais (PEREIRA, 2011, p. 40). Em entrevistas integradas ao acervo do CPDOC/FGV, Mundinha e Magno Cruz, que também foi presidente do CCN, esclarecem que, inicialmente, a distribuição e a apresentação do material eram acordadas diretamente com as escolas, ficando sujeitas à boa vontade dos diretores; porém, em um segundo momento, por volta de 1982, o CCN conseguiu firmar um convênio com a Secretaria de Educação, visando tanto ampliar e facilitar o contato com as escolas, quanto engajar os professores no projeto (PEREIRA, 2011, pp. 40-41). Vê-se, pois, nessa ocorrência, um gesto importante de aproximação entre militância e Estado, que coincide com o marco temporal das ações parlamentares que elencamos no início deste artigo.

Com os ares de renovação que caracterizaram a busca pela redemocratização do país no final da década de 1980, surgem movimentações por parte do poder público assinalando certa possibilidade de ação conjunta com a militância negra. Considerando que a denúncia da "ideologia escolar dominante" (GONÇALVES; SILVA, 2000, p. 155) - das quais foram alvo diferentes instâncias do ensinoaprendizagem (materiais escolares, currículos, formação de professores etc.) (ibidem) - vinha assumindo gradativamente um lugar de destaque nas lutas do movimento negro por uma efetiva democratização do ensino, ganham força no final do século pautas como a questão do racismo presente em livros didáticos das redes oficiais de ensino. Foi então que a abertura ao debate com as organizações públicas permitiu, por exemplo, um contato direto e inédito de instituições negras com os responsáveis pelo Programa Nacional do Livro Didático (PNLD), supervisionado, à época, pela Fundação de Assistência ao Estudante (FAE), evento ocorrido na ocasião do "Seminário Educação e Discriminação dos Negros", realizado em 1987, em Belo Horizonte (MG). Na apresentação dos anais do Seminário, compilados no livro Educação e Discriminação dos Negros (1988), anuncia-se uma "abertura do pensamento pedagógico aos processos e movimentos sociais" e reforça-se a importância de se considerar, no contexto de formulação das políticas públicas, "a prática política dos movimentos negros, as possíveis contribuições desta à prática educativa, bem como o reconhecimento de parcerias a nível dos movimentos sociais [...]" (MELO \& COELHO, 1988, p. 9).

É interessante notar que, contrastivamente aos focos de ação de outros períodos do movimento negro, a discussão da educação do negro situa-se então, na ocasião do Seminário, entre os debates sobre cidadania e direitos, e que, portanto, ela passa a ser entendida como um problema de responsabilidade do Estado, e não da população afrodescendente, conforme evidencia, inclusive, uma das passagens da conferência de encerramento:

${ }^{6}$ Carta disponível em $<$ https://movimentonegrounificadoba.files.wordpress.com/2013/10/carta-de-princc3adpios-domovimento-negro-unificado.doc $>$. Acesso em $<12 / 12 / 2018>$. 
Os negros são também consumidores de livros didáticos, não se podendo esquecer que, embora a compra destes se faça via Estado, é a população negra importante consumidora e se constitui em significativa parcela de contribuintes na sociedade. Neste sentido, entendem os movimentos negros ter o direito de exigir um produto que não os discrimine, sobretudo quando este é adquirido com recursos públicos. (GONÇALVES, 1988, p. 122).

O referido evento configura-se um importante exemplo dos diferentes encontros motivados pelo contexto sócio-histórico de 1988, ano do centenário da abolição da escravatura e da aprovação da Constituição Federal, ocasião a partir da qual passam a surgir novas configurações de ação envolvendo as lutas dos negros no campo da educação, inclusive no que tange ao ensino superior. Se a atenção dada aos livros didáticos no final da década de 1980 atesta a preocupação com a descolonização da educação básica, a emergência de discussões sobre a necessidade de ações afirmativas, em geral, e sobre a importância das cotas raciais, em particular, aponta a mesma postura diante dos problemas identificados no acesso às universidades. Em linhas gerais, o deslocamento de olhar para a educação superior que marca as lutas da década de 1990 também pode ser lido como fruto de um conjunto de novas ações informais de ensino orquestradas pelo movimento negro, no sentido em que muitas entidades atuaram para "levar jovens negros às universidades através da criação dos primeiros 'pré-vestibulares para negros e carentes', que de maneira diferente das ONGs, têm como base o trabalho voluntário realizado por professores e coordenadores de seus núcleos" (PEREIRA, 2013, p. 315).

Salvaguardada a inquestionável relevância das lutas empreendidas a partir de então, consideramos que os pormenores de tal período fogem ao escopo da breve revisão historiográfica por nós proposta ${ }^{7}$. Ainda que a lei 10.639/2003 traga implicações à formação docente, afetando assim os cursos de licenciatura de muitas universidades, entendemos que são, com relação à esfera social, os discursos e as ações inscritos no período de 1920 a 1980, por se centrarem com mais afinco na educação básica, os que mais diretamente fundamentaram o teor da alteração curricular conquistada em 2003 pelo movimento negro, razão pela qual não abordamos detalhadamente a história, tão recente, da educação das demandas educacionais dos negros após 1990.

Reconhecendo, portanto, os limites deste artigo, e conforme anunciado na introdução, a seção seguinte dedica-se à revisão da trajetória do movimento indígena no campo do saber e ao seu respectivo papel na aprovação da lei de 2008, visando tecer, por fim, comparações entre os dois quadros.

\section{Precursores sociais e jurídicos da lei $\mathrm{n}^{\circ}$ 11.645/2008}

O primeiro contato dos povos indígenas com a educação escolar ocorreu no período colonial, através das missões religiosas do cristianismo, vindas de Portugal. Objetivando "aniquilar suas culturas e incorporar mão-de-obra indígena à sociedade nacional” (FERREIRA, 2001, p. 72), as missões se fundamentavam na catequese e no ensino obrigatório de português, em detrimento da manutenção das culturas e das línguas nativas. Concernente a este ponto, é bastante relevante estabelecer, a priori, a distinção entre "educação" e "escolarização", recordada por Fontan (2017): a educação indígena, "transmitida por cada povo indígena, por meio da educação tradicional” (p. 64), é "anterior e insubstituível" à educação escolar indígena, esta sim inicialmente imposta pelos colonizadores e religiosos, no século XVI, e posteriormente demandada e reformulada pelo próprio movimento indígena, no século XX (p. 67).

No contexto da fase coercitiva de escolarização indígena, marcada por forte violência física e simbólica, vê-se um ensino movido pelos preceitos da dominação cultural tida como favorável à dominação territorial almejada. Embora seja correto assinalar que, de modo geral, a educação jesuítica colonial centrada na catequização dos índios começou a perder força já no século XVII - devido tanto à gradual diminuição das populações ameríndias, quanto ao crescente interesse direcionado à educação dos filhos dos colonos (FERREIRA JR, 2010, p. 26) -, e também a despeito do fato de a extinção oficial

\footnotetext{
Para ter acesso a mais informações sobre a demanda e a conquista de cotas para negros nas universidades, vide os depoimentos compilados no capítulo "Debates atuais", do livro Histórias do movimento negro no Brasil: depoimentos ao CPDOC (ALBERTI \& PEREIRA, 2007, pp. 394-427).
} 
do ensino jesuítico no país ter ocorrido no século seguinte, por meio do Alvará de 28 de junho de 1759 , em decorrência das reformas pombalinas, sabe-se que a influência da ideologia de assimilação e de aculturação das organizações religiosas perdura com veemência até o século XIX e com alguma intensidade até mesmo na primeira metade do século XX. No final do período colonial, por exemplo, apesar da existência de casos bem sucedidos de resistência indígena, há relatos de que em escolas salesianas instauradas em aldeias do estado do Amazonas "crianças eram separadas de suas famílias e, fundamentalmente, investia-se na capacitação profissional dos índios, como forma de produzir mão-deobra barata para a população não-índia circunvizinha" (FERREIRA, 2001, p. 73). Segundo D'Angelis (2012, p. 22), são muitos os registros de instalação de internatos nas aldeias indígenas durante e após o Brasil Império (1822-1889), os quais proibiam o uso das línguas maternas, sendo que "alguns [internatos] se mantiveram até quase a década de 1980".

É somente no século XX que surgem, entre muitas controvérsias e muitos interesses escusos, os primeiros sinais de ação do Estado em prol da assistência indígena, marcados pela criação do Serviço de Proteção aos Índios (SPI), em 1910, e por sua posterior substituição/restauração por meio da Fundação Nacional do Índio (Funai), em 1967 (FERREIRA, 2001, pp. 74-75). Embora o ensino religioso perdesse um pouco de espaço nas escolas para crianças indígenas disseminadas pelo SPI, "essas escolas não se distinguiam das escolas rurais do país", uma vez que mantinham a imposição da leitura e da escrita em Língua Portuguesa (D'ANGELIS, 2012, p. 22), bem como o enfoque na formação para o trabalho - trabalho agrícola para os meninos; trabalho doméstico para as meninas (FERREIRA, 2001, p. 75).

Outra ressalva mostra-se pertinente no que diz respeito ao, aparentemente positivo, reconhecimento do bilinguismo e do ensino de língua nativas presente no "Estatuto do Índio" (1973), apoiado nesse período pela Funai. D’Angelis (2012, p. 23) esclarece que, na prática, “a Funai efetivamente encarnou e representou, em todos os níveis, a política indigenista dos governos militares", de modo que a parceria com os pesquisadores norte-americanos da Summer Institute of Linguistics (SIL), por exemplo, culminou na oferta de um ensino bilíngue "de transição", pautado pela desvalorização da língua indígena, "à qual se designa apenas o papel de ponte para levar à introdução e domínio da língua nacional" (ibidem). Trata-se de uma ação em consonância com os ideais das Constituições anteriores à de 1988 (isto é, de 1934, de 1946 e de 1967), que, conforme explica Fontan,

faziam referência à 'incorporação dos silvícolas à comunidade nacional. Ou seja, [segundo esses documentos] não se buscava proteger a diferença existente, e sim desprezá-la ante a dita cultura civilizada e evoluída. [...] [E] a almejada integração ocorreria com o ensino e a educação, os quais proporcionariam meios para a gradual incorporação os índios à 'sociedade nacional" (FONTAN, 2017, p. 78).

Em meados dos anos de 1970, em meio, portanto, a um histórico de influências negativas da Igreja e do Estado nos percursos educacionais dos povos originários, a articulação dos indígenas, incentivada por organizações não governamentais favoráveis à causa, propiciou o surgimento do movimento indígena tal qual o conhecemos hoje. Ironicamente, é tida como fundamental nesse processo uma entidade ligada ao setor progressista da Igreja Católica, o Conselho Indigenista Missionário (CIMI), de 1972, que se afasta dos históricos fins religiosos da Igreja para apoiar a aproximação dos povos indígenas de diferentes regiões. O pesquisador e escritor indígena Daniel Munduruku (2012, p. 45) explica que até esse momento "cada comunidade ou cada povo procurava defender apenas seus interesses, não se dando conta de que outros povos e comunidades viviam em situações semelhantes", daí a importância de assembleias como a patrocinada pelo CIMI em 1974, no estado do Mato Grosso, na qual, de forma inédita, se reuniram lideranças indígenas (p. 41). Também de acordo com Munduruku, reuniões desse tipo "foram as principais fontes da criação de uma consciência pan-indígena em que as lideranças começaram a ter uma atitude macrorregional com relação às demandas dos outros povos indígenas brasileiros", haja vista essas reuniões terem dado condições à transformação de demandas locais, de cada aldeia, em pautas comuns a todos os indígenas (MUNDURUKU, 2012, p. 52).

Inscrito nesse período de grandes eventos, o "Encontro Nacional sobre Educação Indígena”, ocorrido em 1979 e organizado pela Subcomissão de Educação da Comissão Pró-índio de São Paulo (SP), ilustra o teor das ações do movimento indígena que precederam a conquista de políticas oficiais no campo da educação escolar dos índios. Reunindo professores, antropólogos, linguistas e 
outros profissionais que, juntamente com membros das comunidades indígenas, atuavam, na época, em escolas indígenas de diferentes estados do país, o evento promoveu uma importante troca de relatos e de perspectivas. Ao encontro do caráter segmentário descrito por Daniel Munduruku, as experiências compartilhadas na ocasião foram descritas como sendo ainda "bastante isoladas, resultando mais do entusiasmo e intuição de uma pessoa do que projetos institucionais, programadas. Dessa forma, aquele momento do encontro e [o livro dele resultante] eram oportunidades para que se as analisassem, ampliassem e aprofundassem, tirando-as do isolamento" (CAPACLA, 1995, p. 57).

Similares às escolas mantidas pelo movimento negro do século XX, as iniciativas indígenas que caracterizam essa fase da escolarização do índio também funcionavam, em maior ou menor medida, paralelamente às redes oficiais de ensino, apoiadas sobretudo por organizações não governamentais. Não sem razão, eventos como o o supracitado, por reunirem representantes de escolas de Norte a Sul do país , contribuíram para a posterior tradução política das pautas indígenas para o campo da educação, uma vez que essas trocas possibilitavam tanto a identificação das especificidades de ensino das diferentes etnias, quanto a compilação de pautas comuns (para detalhes sobre Encontro de 1979, vide DA SILVA, 1979 e CAPACLA, 1995).

Destarte, uma vez (re)unido e, por conseguinte, mais organizado, o movimento indígena passa a cobrar do Estado, a partir do final da década de 1970, o exercício da cidadania dos povos originários, sendo o direito a terra sua maior bandeira, devido ao papel central da floresta na manutenção de suas culturas. Tomando como referência as experiências educacionais conduzidas até então pela própria militância, clama-se, na esfera da educação, o acesso a uma educação escolar diferenciada, que garantisse a preservação de suas culturas e que rompesse de forma definitiva com a lógica integracionista. Imersos num contexto sociopolítico de união de diversos grupos sociais em prol do fim da ditadura militar e, consequentemente, a favor da redemocratização do país, os indígenas passam a reiterar a necessidade de um ensino "diferenciado", "específico", "intercultural" e "bilíngue", nos moldes do modelo de educação que viria a ser oficialmente reconhecido pela Constituição de 1988 (BRASILMEC/CNE, 1999, p. 9). Observa-se, assim, no final do século XX, uma mudança de paradigma com relação à escolarização, na medida em que "firmava-se a ideia de que a escola poderia ser algo 'a favor ' dos índios: instrumento de acesso a informações e conhecimentos vitais para sua sobrevivência e para sua autodeterminação" (DA SILVA, 2001, p. 31). A educação escolar ganha para esses povos um sentido de educação complementar, de forte viés político, pois, já no Encontro Nacional de 1979, os movimentos indígenas reconheciam, por exemplo, a "urgente necessidade [do domínio da língua portuguesa] nas situações de contato" (CAPACLA, 1995, pp. 58-59). Assim, "mesmo com todos os desafios colocados para os povos indígenas quando estes decidem instituir uma escola, esta instituição é considerada importante quando está a serviço das lutas políticas e identitárias" (BONIN, 2015, p. 2).

Com o objetivo de atender a tais fins, as escolas indígenas, em oposição às escolas convencionais, passam a assumir diversas particularidades, sempre orientadas pela intenção de diálogo com a educação indígena tradicional, não escolarizada ${ }^{8}$, que se ancora, com frequência, na transmissão comunitária dos saberes ancestrais, nas narrativas orais e, também, na soma da educação do corpo, da mente e do espírito (MUNDURUKU, 2012). Marcada pela adoção do bi ou multilinguismo e pela prescrição de professores também indígenas, bem como pela possibilidade de flexibilização curricular e estrutural consoante às necessidades de cada etnia, a educação escolar indígena é formalizada com base em princípios como o da interculturalidade e o da coletividade, mas sem, com isso, negar a responsabilidade do Estado no que tange à garantia desse direito (BRASIL-MEC/CNE, 1999, pp. 3136).

Para termos a dimensão de como funcionou, em termos práticos, a construção das escolas diferenciadas, cabe a leitura do relato de experiência de Gersem dos Santos Luciano, conhecido como Gersem Baniwa, importante intelectual e professor indígena envolvido com a causa da educação, que

\footnotetext{
${ }^{8}$ Nas palavras do educador indígena Gersem Baniwa, na educação indígena tradicional "se aprende a viver bem, ser um bom caçador, um bom pescador, um bom marido, uma boa esposa, um bom filho (...) a fazer roça, plantar, fazer farinha, canoa, cestarias, cuidar da saúde, a benzer, curar doenças, conhecer plantas medicinais, aprende geografia das matas, dos rios, cacuri, etc. Os conhecimentos específicos como o dos pajés, estão a serviço e ao alcance de todos. [...]" (Baniwa apud FONTAN, 2017, p. 64).
} 
atuou diretamente na conformação das escolas indígenas no município São Gabriel da Cachoeira (AM), no final da década de 1990:

Assim que terminei a Graduação na Universidade Federal do Amazonas (UFAM), atuei 3 anos como secretário de Educação do município de São Gabriel da Cachoeira (AM), entre 1997 e 1999. Eu era muito jovem, pouco entendia e pouco conhecia o ambiente da política governamental. [...] Foi uma grande aprendizagem e também grande desafio de transformar as escolas rurais, como eram chamadas as escolas implantadas nas aldeias com o curriculo colonial, integracionista e perseguidor dos conhecimentos e culturas indigenas, para escolas indigenas autogeridas, com currículos interculturais $e$ bilíngues. Para isso inicialmente tivemos que elaborar e aprovar todo o arcabouço legal e normativo educacional do município, para depois iniciarmos as mudanças curriculares, pedagógicas e de gestão das escolas indígenas.

Os 4 anos na Secretaria de Educação foram fundamentais para os compromissos posteriores. Nós mudamos totalmente a diretriz política do município, que era um município comum, com leis seguindo as diretrizes e as políticas nacionais, sem nenhuma diferenciação para os povos indígenas, que representam $90 \%$ da população do município. Durante os 4 anos à frente da Secretaria de Educaşão do município, conseguimos mudar todo o arcabouco legal para possibilitar a construção de escolas diferenciadas. Escolas que não proibissem mais as linguas e que passassem a valorizar os conbecimentos indigenas. Comecou-se a discutir material didático específico nas línguas indígenas, isso numa época em que, mesmo na academia, esse tema era muito pouco discutido. Pouca gente se dedicava a esses temas e não tinha literatura: nossa missão era uma espécie de aventura. (destaques nossos) (LUCIANO, 2012, p. 128).

É possível depreender desses excertos que as lutas dos indígenas brasileiros por uma educação diferenciada simbolizam uma luta pela descolonização do próprio conceito de escola, um enfrentamento dos projetos e dos modelos educacionais de matriz colonial historicamente vigentes no país. E, por essa razão, "negar a educação escolar pelo fato de estar, substancialmente, imbricada em uma ideologia dominante, [romperia] com a possibilidade de moldá-la para que se compatibilize com o respeito ao modo peculiar de vida e cultura dos povos indígenas" (FONTAN, 2017, p. 66).

Nesse contexto, são muito relevantes as estratégias envolvendo a resistência à dominação linguística, das quais resulta, em última instância, a literatura indígena. Naturalmente, inúmeras foram e são as reflexões (de índios e não índios) sobre a questão da alfabetização e da necessidade de escrita dos povos indígenas, tendo em vista sua tradição oral. Como já mencionado, a demanda pela proficiência (oral e escrita) em língua portuguesa surge fortemente embasada no uso social e político do português em situações de contato com os não indígenas, mas, não por isso, é desconsiderado seu potencial no que tange, também, à divulgação das culturas autóctones, pois

O conhecimento da língua portuguesa permite que as populações indígenas conheçam o funcionamento da sociedade envolvente e, ainda, que elas tenham acesso a informações e tecnologias variadas. A produção de textos indígenas em língua portuguesa contribui também, em sentido inverso, para que a sociedade envolvente - e a humanidade como um todo - conheça melhor as sociedades indígenas e, com isso, enriqueça-se culturalmente. Os textos produzidos em língua portuguesa, ou para ela traduzidos, nas escolas e comunidades indígenas, têm sido uma forma privilegiada de divulgação dos conhecimentos tradicionais e de afirmação étnica. Esses materiais fornecem dados importantes sobre as diferentes culturas indígenas e suas tradições, permitindo que, através deles, a diversidade cultural no país torne-se mais evidente e possa ser mais respeitada. (BRASIL-MEC/SEF/DPEF, 1998, p. 121).

Com o gradual reconhecimento jurídico das escolas diferenciadas, muitas etnias passam a correlacionar a escrita indígena à preservação e à disseminação de suas culturas, considerando também a possibilidade de disseminação de seus valores e saberes para além dos limites de seus territórios. Contudo, diferentemente do que observamos nos posicionamentos do movimento negro do século XX, essa postura favorável à valorização das culturas indígenas entre os não indígenas não parece se tornar substancial a ponto de fazer emergir um efetivo e organizado interesse pela modificação dos currículos das escolas convencionais. Isso porque, como nos mostra a história da educação desses povos, a especificidade da violência simbólica por eles sofrida culminou na imprescindível luta pela marcação da diferença, e não da igualdade, na educação, o que explica a demanda por uma escola indígena, e não pelo 
acesso ou pela modificação do sistema oficial de ensino, bem como fornece subsídios para a compreensão de alguns pormenores do contexto de aprovação da lei 11.645/2008.

Apresentado logo após a promulgação da lei 10.639/2003, o projeto que deu origem à alteração ocorrida em 2008 (PL 433/2003), de autoria da Deputada Mariângela Duarte (PT/SP), trazia em sua justificação a afirmação de que "a referida lei [10.639] foi criticada [...] pela comunidade indígena, que não foi contemplada com a previsão de disciplinas para os alunos conheceram a realidade indígena do país" (BRASIL-DCD, 2003, p. 13940). Além de enfatizar a importância da cultura indígena no Brasil, o documento anuncia-se como uma "manifestação de povos indígenas do Estado do Acre", sem especificar, porém, quais as etnias que estariam vinculadas à reivindicação. Trata-se, afinal, de um texto dotado de certas lacunas explicativas acerca dos agentes e dos fatos sociais envolvidos na ação. Sozinho, ele não esclarece, com precisão, os caminhos que levaram à presente proposta.

Visando obter mais detalhes sobre as origens do projeto e sobre a atuação do movimento indígena frente ao pedido formal de modificação da lei de 2003, Nobre (2017) recorre a uma pesquisa documental no periódico Porantim, publicado pelo CIMI desde 1978. No período de 2003 a 2008, em que ocorria no Congresso Federal grande parte das discussões sobre a alteração da lei 10.639/03, nenhuma publicação crítica ou significativa acerca do tema foi encontrada pelo pesquisador. Verifica-se, ao contrário, que a revista se limitou apenas à publicação do texto original da lei 11.645 na ocasião de sua aprovação, sem se aprofundar no assunto. Assim, é possível interpretar que "os editores do jornal tinham pouco ou mesmo nenhum conhecimento sobre a tramitação desse projeto, ainda mais se considerarmos que as conquistas frutos de mobilização de organizações indígenas ou indigenistas costumam ser bastante celebradas no periódico, o que não aconteceu com a Lei em questão. Nas edições seguintes, o assunto não é mais mencionado" (NOBRE, 2017, p. 40).

Ao encontro da hipótese que de "a Lei 11.645/08 foi mais uma iniciativa de parlamentares sensíveis ao tema do que propriamente de organizações indígenas ou indigenistas” (p. 40), ganha destaque, novamente, uma declaração do militante e educador indígena Gersem Baniwa (ou Gersem dos Santos Luciano):

\begin{abstract}
A escola é a instituição e o lugar privilegiado e estratégico para reduzir ou eliminar a intolerância, o preconceito, a discriminação e o racismo entre pessoas e povos. A Lei 11.645 é, portanto, uma excelente oportunidade e possibilidade para isso. Agora, nós temos alguns desafios. Embora seja um instrumento importante, nós não estávamos preparados para isso porque veio um pouco cedo, do ponto de vista da construção mental, do imaginário. Veio mais como possibilidade. Nós” quem? Tanto nós indígenas, quanto a sociedade não indígena. Isso foi uma luta aproveitada do movimento negro, pela articulação afrodescendente, e a gente conquistou esse direito muito importante. (destaque nosso) (LUCIANO, 2012, pp. 141-142 apud NOBRE, 2017, p. 40).
\end{abstract}

Na leitura de Nobre (2017, p. 40), "por essa fala entende-se que houve pouca participação indígena na construção da Lei, e mesmo um sentimento de surpresa com sua publicação".

Longe de desmerecer o papel desempenhado pela militância indígena no campo político, tais dados e argumentos fornecem indícios sobre as diferenças estabelecidas entre os caminhos percorridos pela lei de 2003 e pela lei de 2008 no tocante ao engajamento dos movimentos negro e indígena em cada um desses processos. Enquanto é comum encontrarmos, por exemplo, documentos e relatos que celebrem a lei 10.639 como uma conquista do movimento negro, tendo em vista, inclusive, a evidente participação de parlamentares negros e militantes em seu processo burocrático e legal, não houve até o momento uma identificação equivalente de atores sociais do movimento indígena em relação à aprovação da lei 11.645.

Outros depoimentos de Gersem Baniwa por nós localizados corroboram essa percepção. Ao discorrer, por exemplo, sobre a falta de material didático como um provável empecilho à implantação da lei de 2008, ele ilustra que, de fato, os indígenas, e também pesquisadores, voltaram-se, ao longo do tempo, quase que exclusivamente à produção de materiais que atendessem especificamente às escolas indígenas, e não ao alunado em geral:

Percebe-se uma movimentação interessante e cada vez maior por um lado, de pesquisadores, autores, artistas e professores indígenas e não indígenas na produção de livros e materiais didáticos de apoio docente ou mesmo de apoio discente nas universidades, e por outro lado, 
um interesse crescente do mercado editorial. Isso é muito bom, pois, representam raras possibilidades e oportunidades que precisam ser valorizadas, potencializadas e adequadamente aproveitadas. O problema é que os indígenas ou mesmo não indígenas interessados na questão ainda são poucos e enfrentam gigantescas dificuldades para se dedicarem a esse trabalho. Não existe linha de financiamento público para isso, o que é uma pena, pois isso fragiliza e põe em xeque o futuro da Lei. Além disso, entre os poucos autores, pesquisadores e professores indígenas não há experiência acumulada de produção de livros e materiais didáticos voltados para esse público das escolas não indígenas. Toda experiência existente no campo da produção literária indigenista está focada em produção de material didático para a alfabetização de crianças indígenas por meio das famosas "cartilhas bilíngues". Nunca se produziu livros e materiais didáticos para além disso, para as séries finais do ensino fundamental e ensino médio, muito menos para os iniciantes dos cursos superiores de graduação, é claro, com raríssimas exceções. (destaque nosso) (LUCIANO, 2016, p. 21).

Declarações como as deste importante educador e pesquisador indígena levam-nos a perceber, então, alguns contrastes entre as ações dos indígenas e dos negros no que concerne às demandas que embasam as leis por nós estudadas. Enquanto os primeiros tiveram que somar esforços para assegurar o funcionamento das escolas diferenciadas, os militantes do segundo grupo, como exposto anteriormente, chegaram a se dedicar, sobretudo a partir da década 1980, à produção de materiais alternativos para as escolas convencionais, sem se manterem restritos à produção de conteúdos para as escolas fundadas e dirigidas por organizações negras. Esse dado é especialmente interessante se pensado à luz do relato de Gersem Baniwa sobre o papel dos materiais didáticos no contexto do cumprimento das leis, no qual ele aponta a falta de clareza/consenso, por parte dos próprios indígenas, acerca de quais conteúdos devem fundamentar a aplicação da lei 11.645/2008 nas escolas não indígenas:

Temos grandes desafios: primeiro, não temos materiais didáticos educativos! $\mathrm{E}$ me parece que é difícil produzir material didático para atender essa orientação normativa, pela própria complexidade que é. Veja: nós estamos falando de informações, de conhecimentos sobre os índios, para não índios. Então, o primeiro desafio é como os povos indígenas vão se apropriar dessa ferramenta para divulgar seus conhecimentos, seus valores, suas culturas e tradições. Ainda não vejo o movimento indígena mobilizado para isso. Essa é a principal dificuldade. A primeira pergunta é: $O$ que os povos indigenas querem que os não indios saibam deles?". Isso já é um enorme problema, porque teremos muitas dificuldades para os próprios índios definirem isso, diante da grande diversidade de povos, realidades locais e contextos históricos. São os índios que devem definir o que querem e como querem ser conhecidos pela sociedade nacional. "Que tipo de conhecimento querem divulgar?" Aos povos indígenas, muitos conhecimentos seus não interessam que os brancos fiquem sabendo, pois nem internamente são de domínio público, como são os conhecimentos dos pajés. Teremos muitas dificuldades para classificar quais são os conhecimentos que podem ser levados ao conhecimento dos não índios. (destaque nosso) (LUCIANO, 2012, p. 142).

Eis aqui um importante contraste nos percursos das leis 10.639/03 e 11.645/08: ainda que os materiais didáticos produzidos pelo movimento negro não tenham sido diretamente aproveitados ou apropriados pela lei de 2003, nota-se nos documentos oficiais que orientam sua implantação (BRASILMEC/SECAD, 2006; BRASIL-MEC/SECADI, 2013; BRASIL-MEC/SEPPIR, 2008; BRASILMEC/SEPPIR, 2004) certo diálogo com os conteúdos historicamente recordados pela militância negra através de cartilhas e manuais independentes. Personagens e momentos históricos da cultura negra que outrora fundamentaram ações independentes no campo do saber ecoam, hoje, nas medidas formais adotadas pelo Estado a partir da lei 10.639/2003. Já a fala de Baniwa sobre uma mobilização indígena pouco expressiva no que tange à indicação e à definição dos conteúdos a serem ensinados aos não índios, somada aos dados e eventos que elencamos neste estudo, indica, por outro lado, que a diferença de trajetória dos dois movimentos tenha, possivelmente, implicações na própria implantação das leis. Tratase, assim, de duas leis de recorte multicultural e descolonial, mas marcadas pelas particularidades de cada contexto de luta.

No artigo "Educação, literatura e direitos humanos: visões indígenas da lei 11.645/08" (2011), a pesquisadora Graça Graúna desenvolve um rico trabalho ao aplicar um questionário sobre a lei de 2008 a indígenas de diferentes etnias "com o objetivo de enfatizar a visão indígena em torno do assunto" (GRAÚNA, 2011, p. 231). Composto por duas perguntas, "1. Quais os desafios e perspectivas para o ensino da história e da cultura indígenas?" e "2. De que modo a história e a cultura indígena são 
referidas no livro didático hoje?” (GRAÚNA, 2011, p. 239), o inquérito que fundamenta as entrevistas foi respondido por dezenas de indígenas, sendo que doze conjuntos de respostas são disponibilizados no artigo em questão.

Nas falas dos indígenas entrevistados, é possível notar pontos comuns relativos ao que eles identificam como sendo os desafios a serem enfrentados pela lei de 2008, tais como: o desconhecimento da diversidade cultural e étnica dos povos indígenas e os respectivos estereótipos expressos em livros didáticos; a hegemonia de narrativas e de visões não indígenas, sobretudo no que abrange a história desses povos, em particular, e a história do Brasil, em geral; a persistência da imagem do indígena presa ao passado, especialmente ao período colonial, em vez da figura do indígena contemporâneo. Embora apareça entre as respectivas soluções sugeridas pelos entrevistados a insistente defesa de materiais produzidos pelos próprios indígenas, reconhece-se que, em se tratando do ensino da História e da Cultura dos povos indígenas em escolas não indígenas, existem empecilhos específicos a serem superados, como expõem, respectivamente, Juvenal Teodoro Payayá, do povo Payayá, e Nádia Akau, do povo Tupinambá de Olivença (Ilhéus-BA):

Primeiro, é saber a serviço de quem está a lei 11.645. Em síntese: é sabido que não existem suficientes professores índios preparados para trabalhar com tais disciplinas, nem para produzir o material didático necessário, [e que transmitam] a visão do povo que não teve ainda esta oportunidade de contá-la. Fica a lei para ser usada com a compreensão do outro. Ora, isto já existe em menor tamanho. Este é o desafio: poder contar nossa própria história com o sentimento de quem viveu, de quem deseja continuar verdadeiramente a viver a herança de uma ancestralidade singular; ter consciência de que as mudanças são relativas, que o que se diz útil o é para poucos, e que nem sempre as mudanças precisam acontecer. (Payayá apud GRAÚNA, 2011, p. 245).

Hoje as escolas indígenas já têm o maior acervo de materiais específicos das diversas culturas em nível nacional e estadual referindo-se à Bahia. Mas esse material ainda não atende às escolas não indígenas que estão sendo obrigadas pela lei a implementar o ensino dessas culturas [...]. (Akau apud GRAÚNA, 2011, p. 249).

Os relatos presentes nos dois excertos corroboram, em certa medida, parte das observações que fizemos a respeito do grau de participação do movimento indígena nos processos de promulgação e de implantação da lei 11.645/08, se comparado ao engajamento do movimento negro frente à lei de 2003, merecendo atenção o aspecto reforçado por Payayá acerca da impossibilidade de os indígenas, em especial de os educadores indígenas, arcarem com a responsabilidade de produzir o material necessário à efetivação do ensino dos conteúdos determinados pela nova legislação, uma função que, de fato, não deve/deveria ser atribuída a eles. Isso posto, não deixa de ser relevante observar que, a exemplo do que mostra a questão dos materiais escolares que historicamente atendem ao modelo convencional de ensino, as particularidades das pautas de cada movimento fizeram com que negros se dedicassem com maior intensidade do que indígenas à modificação e à ampliação dos currículos oficiais.

Chegado a esse ponto, é importante ressaltar que, a despeito de tais diferenças entre os percursos da militância indígena e negra, é incontestável que "a Lei 11.645/08 não foi uma dádiva concedida a um grupo inerte, pois seu histórico de lutas e mobilizações lhes deu a visibilidade que propiciou a atenção a suas demandas, ainda que a partir da iniciativa de não indígenas. Nesse sentido, a Lei não deixa de ser, também, uma conquista de sua mobilização" (NOBRE, 2017, pp. 42-43). Prova disso está, por exemplo, na descrição que Grupioni (1995) faz do teor de encontros e de manifestações de professores indígenas no final da década de 1980 e no início da década de 1990, que revela preocupação com o imaginário que sustenta o ensino da cultura indígena nas escolas convencionais, mostrando que os índios não permaneceram alheios ao tema:

Nos encontros de professores indígenas, que têm acontecido em todo o território nacional, estes além de discutirem a situação de suas escolas, têm também se pronunciado sobre este tema. No documento final do I Encontro Estadual de Educação Indígena do Mato Grosso, realizado em maio de 1989, os professores indígenas daquele estado registraram como uma de suas conclusões, que a sociedade envolvente deve ser educada no sentido de abolir a discriminação histórica manifestada constantemente nas suas relações com os povos indígenas”. Os professores indígenas de Rondônia, também reunidos por ocasião de seu I Encontro em 1990, no documento que 
encaminharam aos Senadores da República, solicitaram a colaboração destes "para que se respeite os índios e suas culturas nas escolas não-indígenas e nos livros didáticos". $\mathrm{Na}$ "Declaração de Princípios dos Povos Indígenas do Amazonas, Roraima e Acre", escrita em julho de 1991 pelos professores indígenas e reafirmada em outubro de 1994, está firmado como princípio que nas escolas dos não-indios, será corretamente tratada e veiculada a história e cultura dos povos indígenas brasileiros, a fim de acabar com os preconceitos e o racismo". (destaques nossos) (GRUPIONI, 1995, p. 483).

Em consonância com esse excerto, localizamos no livro Atas indigenistas (1988), organizado por Ana Gita de Oliveira e Olympio Trindade Serra, um documento apresentado pela UNI - União das Nações Indígenas do Brasil à Câmara dos Deputados em 1984, na ocasião do Simpósio "Índios e Estado", texto em que a educação não indígena é igualmente discutida. No item VI.2 do campo de Educação, solicita-se que "quando for formulada a política educacional do Estado, tanto uma política específica de educação indígena, quanto à [sic] valorização dada ao índio na educação não indígena, devem ser consideradas" ("Simpósio 'Índios e Estado"' apud DE OLIVEIRA \& SERRA, 1988, p. 72). Por fim, e novamente a partir dos relatos de experiência de Gersem Baniwa, vê-se que, no presente, a lei 11.645/2008 é encarada também como uma possibilidade de desdobramento das ações iniciadas junto às próprias comunidades indígenas, dando margem a um movimento de continuidade no trabalho da militância, sem instaurar necessariamente uma rígida distinção nas frentes de luta:

O curioso dessa história é que o que faço hoje aos ensejos da Lei 11.645, ao falar, divulgar e ensinar sobre as histórias e culturas indígenas para os não índios à época fazia isso aos parentes índios que, por força repressiva de séculos de colonização, haviam abandonado suas principais tradições e estavam em reta final de abandono de suas identidades, línguas e modos próprios de vida. Assim, o meu esforço era falar da importância das nossas culturas, tradições, línguas e modos de vida, ao mesmo tempo tendo que desconstruir o discurso e a prática colonial repressiva até então vigente. (LUCIANO, 2016, p. 16).

Depreendemos assim que, apesar de as iniciativas educacionais do movimento indígena terem tencionado suprir, preponderantemente, as demandas educacionais internas ao movimento, os indígenas não ficaram inertes diante dos efeitos da colonização nas escolas tradicionais. Como vimos, é possível admitir, por um lado, que a lei de 2008 tenha surgido como " uma luta aproveitada do movimento negro" (LUCIANO, 2012, pp. 141-142 apud NOBRE, 2017, p. 40), ou ainda como um efeito colateral (e nem por isso de menor importância) das lutas históricas pela educação escolar indígena diferenciada, intercultural e bilíngue. Mas, por outro, é incontestável o "caráter educativo do movimento indígena", no sentido em que suas mobilizações caminharam em uma dupla direção: "a da formação de quadros para a sua continuidade e a da formação da sociedade brasileira para a existência dos diferentes povos indígenas brasileiros" (MUNDURUKU, 2012, p. 50); consequentemente, "a maior contribuição que o Movimento Indígena ofereceu à sociedade brasileira foi a de revelar - e, portanto, denunciar - a existência da diversidade cultural e linguística" (p. 222), o que preparou solo fértil a diversas conquistas, tais como a própria lei 11.645/2008.

Em síntese, esses pormenores indicam que as particularidades dos enfoques de luta do movimento indígena e do movimento negro acabam por exigir leituras igualmente específicas dos contextos de aprovação das leis 10.639/2003 e 11.645/2008 e, por conseguinte, dos significados das lutas por justiça social, mesmo que o enfrentamento do projeto de base colonial que fundou a educação brasileira afirme-se um elo evidente entre os dois grupos.

A seguir, concluímos o nosso quadro comparativo, articulando-o a reflexões sobre os modos a partir dos quais é possível interpretar as diferentes lutas e políticas de combate às injustiças sociais.

\section{Descolonização da educação: demandas por redistribuição e por reconhecimento}

De acordo com Nancy Fraser (2006), existem duas formas fundamentais de se compreender as injustiças sociais: a partir de questões de ordem econômica ou com base em aspectos culturais. No primeiro caso, o das "injustiças econômicas", verificam-se ocorrências de exploração do trabalho, de marginalização econômica e/ou de privação material (FRASER, 2006, p. 232); no segundo, relativo às "injustiças culturais ou simbólicas", observa-se, por sua vez, a constituição de "padrões sociais de 
representação, interpretação e comunicação" responsáveis pela "dominação", pelo "desrespeito" e/ou pelo "ocultamento" de determinadas culturas (ibidem). Em resposta a elas, consolidam-se diversas formas de combate, com destaque, respectivamente, às "lutas por redistribuição [econômica]" e às "lutas por reconhecimento [cultural]" (FRASER, 2006, p. 232). Nesse sentido, é correto admitir uma correlação entre "políticas de redistribuição" e a luta por igualdade (econômica), de um lado, e entre as "políticas de reconhecimento" e o imperativo do direito à diferença (cultural), de outro.

"Em que pese seu mútuo entrelaçamento", Fraser propõe essas duas categorias de luta a fim de explorar os dilemas políticos advindos, precisamente, da luta concomitante contra as diferentes formas de injustiça social, visto que "os dois tipos de luta estão em tensão; um pode interferir no outro, ou mesmo agir contra o outro" (FRASER, 2006, p. 233). Observemos, por exemplo, como sugere a pesquisadora, a questão da "raça": ao mesmo tempo em que a cor de pele "estrutura a divisão capitalista do trabalho", uma vez que "a divisão racial contemporânea do trabalho remunerado faz parte do legado histórico do colonialismo", ela também tem "dimensões culturais-valorativas, que a inserem no universo do reconhecimento" (p. 235). Portanto, "a 'raça 'também é [...] um modo bivalente de coletividade [....], ainda mais porque as normas culturais racistas e eurocêntricas estão institucionalizadas no Estado e na economia, e a desvantagem econômica sofrida pelas pessoas de cor restringe sua 'voz"' (p. 236).

Dado que tais considerações apontam mais para a coexistência e/ou para a imbricação das duas vertentes de injustiça e de militância, e menos para a abordagem de ocorrências isoladas, a leitura das intersecções entre a busca por "redistribuição" e a busca por "reconhecimento" se mostra produtiva para a conclusão da análise dos fatos e dos discursos precursores das leis por nós investigadas, em especial da lei 11.645/2008.

Verificamos anteriormente que no contexto do movimento negro do século XX a ideia de descolonização do campo do saber tem início com a luta pela descolonização do acesso à educação escolar formal, uma reivindicação que, se interpretada a partir de de Fraser, estaria inserida no âmbito das lutas por redistribuição, pois o analfabetismo e a falta de escolaridade constituíam o principal catalisador da desigualdade econômica experimentada pelos negros no pós-abolição. Por outro lado, a partir da segunda metade do século, a crescente atenção dirigida pela militância negra aos repertórios dos materiais didáticos e dos currículos das escolas regulares pode ser lida como o início de uma articulação entre lutas por redistribuição e lutas por reconhecimento, posto que, além da pauta da igualdade de acesso e de oportunidades, os negros passam a proclamar a importância da marcação da diversidade cultural (ou da diferença) nas instituições escolares, de modo a questionar e a revisar um conjunto de saberes historicamente eurocêntricos. Em outras palavras, soma-se aos esforços pela descolonização do acesso, o interesse pela descolonização de conteúdos, sempre com o intuito de tornar igualitário e democrático o sistema oficial de ensino. Sob esse prisma, a lei 10.639/2003, enquanto medida de reparação de uma injustiça simbólica, vincula-se a esse segundo movimento de descolonização, correspondendo, à luz da teoria de Fraser, a uma "política de reconhecimento", haja vista se tratar de uma lei que contesta o apagamento cultural dos negros perpetuado por séculos pelas/nas escolas brasileiras.

No caso indígena, o quadro analítico fraseriano ganha outros contornos, devido, sobretudo, à especificidade do valor e dos sentidos atribuídos por esse grupo à questão da diferença na esfera educacional. Sabe-se que a principal injustiça econômica enfrentada historicamente pelos povos originários atrela-se à expropriação de suas terras. No entanto, mais do que uma questão de redistribuição, essa negação se interliga de forma bastante contundente às injustiças culturais sofridas pelos indígenas, uma vez que do acesso à terra dependem inúmeras práticas socioculturais das comunidades indígenas, entre elas, a educação, que estabelece, tradicionalmente, um forte vínculo com a natureza/a terra (assim como se nota em relação à medicina indígena, que também depende da floresta e de recursos naturais). Portanto, essa forte intersecção entre luta por redistribuição e luta por reconhecimento, da qual a questão dos territórios indígenas é protagonista ${ }^{9}$, pode explicar, em nossa

\footnotetext{
${ }^{9}$ É importante esclarecer que, devido ao escopo e aos limites do nosso estudo, desconsideramos as discussões sobre a educação do negro em áreas rurais, a saber, a educação quilombola. Reconhecemos, no entanto, que, se analisado sob esse viés, a luta do movimento negro pela educação aproxima-se da luta dos indígenas, pois a reivindicação de um ensino diferenciado e
} 
leitura, a dedicação dos povos indígenas a um modelo diferenciado de educação (com materiais, práticas pedagógicas e currículos específicos) em detrimento de uma maior demanda pela alteração do sistema oficial de ensino. Suas escolas nunca fizeram sentido se pensadas nos moldes e, na maioria das vezes, nos territórios dos não índios. Se para os negros o acesso igualitário à escola formal configurou-se um fator decisivo à integração social, para os indígenas o problema iniciava-se, justamente, na ideia de integração, que sempre funcionou como sinônimo de imposição e de assimilação, uma ameaça a suas culturas, e não uma conquista necessária ao exercício de suas cidadanias, como o foi, por sua vez, aos negros. E é, pois, esse o principal fator que pode explicar as diferentes motivações e os diferentes graus de envolvimento das duas militâncias no que concerne aos caminhos trilhados pelas leis de 2003 e de 2008, respectivamente.

\section{CONSIDERAÇÕES FINAIS}

É comum que a questão da diversidade na educação seja pensada com base na importância de uma consistente transposição didática de saberes representativos da pluralidade cultural, isto é, da tradução didática de, por exemplo, diretrizes e conteúdos postulados por documentos legais, tais quais as leis por nós analisadas. Embora se trate de uma etapa de suma importância e que ainda demanda muitos esforços, este artigo chama a atenção para o fato de que costuma haver, antes dela, um imprescindível movimento de transposição política (vide quadro analítico proposto em DE SÁ, 2019, p. 56). Em outras palavras, nota-se que, antes de saírem dos papéis rumo à sala de aula, propostas alinhadas a uma perspectiva descolonial de educação têm como primeiro deslocamento a saída das ruas em direção à esfera legal. Nesse sentido, o que denominamos aqui de transposição política, em contraposição à já conhecida expressão "transposição didática", dialoga com o que Gomes (2017, p. 50) descreve como sendo uma "efetiva passagem da fase da denúncia para o momento de cobrança de intervenção do Estado e construção de políticas públicas de igualdade racial" e, no escopo deste estudo, também de igualdade étnica. Seja, contudo, na etapa de tradução legal ou na fase de tradução didática de tais reivindicações de diversidade na educação brasileira, entendemos que um elo se mostra evidente: o enfrentamento de heranças coloniais.

Ao admitirmos, então, a existência de um legado colonial na educação brasileira responsável pela perspectiva eurocêntrica que ainda orienta, em maior ou menor grau, a inclusão e a exclusão de conteúdos e de práticas didático-pedagógicas na esfera escolar -, bem como a violência simbólica e as relações de poder que o acompanham, as lutas empreendidas pelos movimentos indígena e negro em prol da diversificação dos currículos começa a ganhar novos sentidos. Observa-se, assim, que suas conquistas estão envoltas em muitos conflitos, pois o projeto educacional brasileiro ancora-se, em certa medida, num modelo de educação que, por séculos, tratou como natural a marginalização física e simbólica desses grupos. Nesse contexto, a introdução, por meio de imposição legal, do ensino escolarizado das histórias e das estórias dos indígenas e dos negros advém, como vimos, do anseio por uma educação democrática, em geral, e pela desnaturalização do monoculturalismo nas escolas brasileiras, em específico. Sem leis como as 10.639/03 e 11.645/08, é provável que a questão da diversidade em sala de aula permanecesse ainda mais refém de iniciativas pessoais e/ou de ações informais de ensino; com elas, por sua vez, tem-se um passo favorável a um questionamento mais aprofundado das estruturas sociais e estatais capazes de reproduzir ou de frear o eurocentrismo historicamente presente no Brasil.

A revisão histórica apresentada neste artigo expõe, em síntese, que, embora na esfera jurídica e no plano curricular a lei 11.645/08, ao atualizar a 10.639/03, tenha aproximado as revindicações das militâncias indígena e negra, nas ruas, contudo, os caminhos trilhados por esses movimentos revelam importantes especificidades. Entre os indígenas, vê-se uma escolarização, de viés assimilacionista,

\footnotetext{
veementemente dependente da demarcação e da posse de terras revela-se ponto comum entre as ações da população indígena e as da população quilombola. Informações e dados sobre a educação quilombola podem ser obtidos em

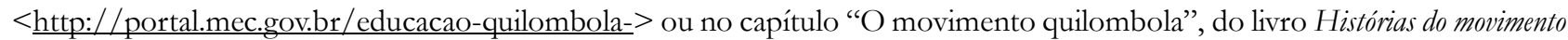
negro no Brasil: depoimentos ao CPDOC (ALBERTI \& PEREIRA, 2007, pp. 310-336).
} 
imposta desde o século XVI; entre a população negra, observa-se um contingente alijado do sistema oficial de ensino até mesmo após a abolição da escravatura. De um lado, portanto, surge a demanda pela diferença na educação, como forma de resistência ao aculturamento; de outro, emerge a reivindicação de uma educação igualitária, como condição para a cidadania. Em comum, por sua vez, vemos militâncias que desenvolvem, de início, ações educativas informais constantemente atravessas por lutas sociais e por demandas jurídicas, promovendo, cada qual a seu modo, um enfrentamento da matriz colonial que sustentou (e que ainda sustenta, em alguma medida) a exclusão educacional, física e simbólica, de grupos tidos como minoritários. Das ruas, através de percursos distintos e entre buscas por reconhecimento e por redistribuição, o mesmo destino: a descolonização do saber e do pensamento.

\section{REFERÊNCIAS}

ALBERTI, Verena; PEREIRA, Amilcar Araujo. Histórias do movimento negro no Brasil: depoimentos ao CPDOC. Rio de Janeiro, RJ: Pallas: CPDOC/FGV, 2007.

BALSALOBRE, Sabrina Rodrigues Garcia. Língua e sociedade nas páginas da Imprensa Negra paulista: um olhar sobre as formas de tratamento. Dissertação (Mestrado em Linguística e Língua Portuguesa). Araraquara: UNESP, 2009.

BONIN, Iara Tatiana. "Educação escolar indígena”. Revista PORANTIM (Cimi), Encarte Pedagógico VI (Patrícia Bonilha [Ed.]), p. 1-4, agosto 2015. Disponível em: <https://cimi.org.br/wpcontent/uploads/2020/01/Porantim377_Ago_Encarte-2015.pdf>. Acesso em: 15/06/2021.

BRASIL. Lei n. 11.645 de 10 de março de 2008. Altera a Lei n. 9.394, de 20 de dezembro de 1996. D.O.U. de 11 de mar. de 2008.

BRASIL. Projeto de lei n. 433/2003. Autoria Mariângela Duarte. Congresso Nacional. Câmara dos Deputados - Brasília, 2003.

BRASIL. Lei n. 10.639, de 9 de janeiro de 2003. Altera a Lei n. 9.394, de 20 de dezembro de 1996. D.O.U. de 10 de jan. de 2003.

BRASIL. Projeto de lei $\mathbf{n}^{\mathbf{o}}$ 259/99. Autoria de Esther Grossi e Ben-Hur Ferreira. Congresso Nacional. Câmara dos Deputados - Brasília, 1999.

BRASIL. Lei n. 9.394, de 20 de dezembro de 1996 (LDBEN-96). Estabelece as diretrizes e bases da educação nacional. D.O.U. de 23 dez. 1996.

BRASIL. Projeto de lei $\mathbf{n}^{\mathbf{0}}$ 75/97. Autoria de Abdias do Nascimento. Senado Federal - Brasília, 1997.

BRASIL. Projeto de lei no 18/95. Autoria de Benedita da Silva. Senado Federal - Brasília, 1995.

BRASIL. Projeto de lei $\mathbf{n}^{\mathbf{0}} \mathbf{6 7 8} / \mathbf{8 8}$. Autoria de Paulo Paim. Congresso Nacional. Câmara dos Deputados - Brasília, 1988.

BRASIL. Projeto de lei $\mathbf{n}^{\mathbf{0}}$ PL 1332/1983. Autoria de Abdias do Nascimento. Congresso Nacional. Câmara dos Deputados - Brasília, 1983.

BRASIL-DCD. "Justificação" do Projeto de lei n. 433/2003. Diário da Câmara dos Deputados. ANO LVIII, n. 044, Brasília-DF, Abril de 2003.

BRASIL-MEC/CNE. Parecer Homologado n. 14/99. Institui as Diretrizes Curriculares Nacionais da Educação Escolar Indígena, Brasília: MEC/CEB, 1999. Disponível em: <http://portal.mec.gov.br/cne/arquivos/pdf/1999/pceb014_99.pdf>. Acesso em: 19/01/2021.

BRASIL-MEC/SECAD. Orientações e Ações para a Educação das Relações Étnico-Raciais, Brasilia: MEC/SECAD, 2006. 
BRASIL-MEC/SECADI. Plano Nacional de Implementação das Diretrizes Curriculares Nacionais para a Educação das Relações Étnico-Raciais e para ensino de História e Cultura Afro-brasileira e Africana. Brasília: MEC/SECADI, 2013.

BRASIL-MEC/SEF/DPEF. Referencial Curricular Nacional para as Escolas Indígenas, Brasília: MEC/SEF/DPEF, 1998.

BRASIL-MEC/SEPPIR. Contribuições para Implementação da Lei 10.639/2003. Brasília: MEC/SEPPIR, 2008.

BRASIL-MEC/SEPPIR. Diretrizes Curriculares Nacionais para a Educação das Relações ÉtnicoRaciais e para o Ensino de História e Cultura Afro-Brasileira e Africana. Brasília: MEC/SEPPIR, 2004.

CAPACLA, Marta Valéria. (Org.). O debate sobre educação indígena no Brasil (1975-1995) - resenhas de teses e livros. Brasília: MEC/MARI-USP, 1995.

D'ANGELIS, Wilmar. Aprisionando sonhos: a educação escolar indígena no Brasil. Campinas, SP: Curt Nimuendaju, 2012.

DA CONCEIÇÃO, Manoel Vitorino. Das reivindicações à lei: caminhos da lei $\mathbf{n}^{\mathbf{0}} \mathbf{1 0 . 6 3 9 / 0 3}$. Dissertação (Mestrado em História Social). São Paulo: PUC/SP, 2011.

DA SILVA, Aracy Lopes. "Uma 'Antropologia da Educação' no Brasil? Reflexões a partir da escolarização indígena”, in.: DA SILVA, A. L., FERREIRA, M. K. L. (Orgs.). Antropologia, História e Educação A questão indígena e a escola, São Paulo: Global, 2001, p. 29-70.

DA SILVA, Aracy Lopes. “Encontro de educação indígena”. Revista de Antropologia, vol. 22, 1979, p. 157-159. Disponível em: <www.jstor.org/stable/41615950>. Acesso em: 19/01/2021.

DE OLIVEIRA, Ana Gita; SERRA, Olympio Trindade (Orgs.). Atas indigenistas. Brasília, DF: Ministério da Educação e Cultura/Secretaria do Patrimônio Histórico e Artístico Nacional/Fundação Nacional Pró-Memória, 1988.

DE SÁ, Ana Paula dos Santos. A descolonização da educação literária no Brasil: das leis 10.639/2003 e 11.645/2008 ao PNLD 2015. Tese (Doutorado em Linguística Aplicada), Campinas-SP: UNICAMP, 2019.

DOMINGUES, Petrônio. “Um 'templo de luz': Frente Negra Brasileira (1931-1937) e a questão da educação”, Rev. Bras. Educ., vol.13 n. 39, Rio de Janeiro Sept./Dec. 2008, p. 517-534.

FERREIRA JR., Amarilio. História da Educação Brasileira: da Colônia ao século XX. São Carlos: EDUFSCar, 2010.

FERREIRA, Mariana Kawall Leal. "A educação escolar indígena: um diagnóstico crítico da situação no Brasil”, in.: DA SILVA, Aracy Lopes, FERREIRA, Mariana Kawall Leal (Orgs.) Antropologia, História e Educação - A questão indígena e a escola. São Paulo: Global, 2001, p. 71-111.

FONTAN, Daiane de Fátima Soares. Educação escolar indígena: estudo sociojurídico da política estatal a partir de Pierre Bourdieu. Curitiba: Juruá, 2017.

FRASER, Nancy. "Da redistribuição ao reconhecimento? Dilemas da justiça numa era 'póssocialista", trad. Julio Assis Simões. Cadernos de campo, São Paulo, n. 14/15, p. 231-239, 2006.

GOMES, Nilma Lino. O movimento negro educador - saberes construídos nas lutas por emancipação. Petrópolis: Vozes, 2017.

GONÇALVES, Luiz Alberto Oliveira "Encaminhamentos propostos”, in.: MELO, Regina Lúcio Couto de; COELHO, Rita de Cássia Freitas. (Orgs.). Educação e discriminação dos negros, Belo Horizonte: IRHJP, 1988, p. 121-122.

GONÇALVES, Luiz Alberto Oliveira; SILVA, Petronilha Beatriz Gonçalves e. "Multiculturalismo e educação: do protesto de rua a propostas e políticas”. Educação e Pesquisa, São Paulo, v.29, n.1, p. 
109-123, jan./jun. 2003,

GONÇALVES, Luiz Alberto Oliveira; SILVA, Petronilha Beatriz Gonçalves e." Movimento Negro e Educação”, Rev. Bras. Educ., n.15 Rio de Janeiro Sept./Dec. 2000, pp. 134-158.

GRAÚNA, Graça."Educação, literatura e direitos humanos: visões indígenas da lei 11.645/08". Educação \& Linguagem, v. 14, n. 23/24, p. 231-260, jan.-dez. 2011.

GRUPIONI, Luís Donisete Benzi. "Livros didáticos e fontes de informações sobre as sociedades indígenas no Brasil", in.: DA SILVA, Aracy Lopes.; GRUPIONI, Luís Donisete Benzi (Orgs.). A temática indígena na escola - novos subsídios para professores de $1^{\circ}$ e $2^{\circ}$ graus. Brasília-DF: MEC/MARI/UNESCO, 1995, p. 481-526.

HALL, Stuart. Da Diáspora: identidades e mediações culturais. trad. Adelaine La Guardia Resende, Ana Carolina Escosteguy, Claudia Alvares, Fracisco Rudiger e Sayonara Amaral. Belo Horizonte: Editora da UFMG, 2003.

LUCIANO, Gersem José dos Santos. “A história e cultura indígena no contexto da Lei 11.645/08: reflexos na educação brasileira" (Entrevista). Revista de Educação do Cogeime - Ano 25, n. 49, p. 11 23, julho/dezembro 2016. DOI http://dx.doi.org/10.15599/cogeime.v25n49

LUCIANO, Gersem José dos Santos.“ Entrevista concedida a Maria Aparecida Bergamaschi”. Revista História Hoje, v. 1, n. 2, p. 127-148, 2012.

MELO, Regina Lúcio Couto de; COELHO, Rita de Cássia Freitas. "Apresentação", in.: MELO, Regina Lúcio Couto de; COELHO, Rita de Cássia Freitas. (Orgs.). Educação e discriminação dos negros, Belo Horizonte: IRHJP, 1988, p. 7- 10.

MUNDURUKU, Daniel. O caráter educativo do movimento indígena brasileiro (1970-1990). São Paulo: Paulinas, 2012.

NOBRE, Felipe Nunes. Nos meandros do (re)conhecimento: a temática indígena em livros didáticos de História no contexto de implementação da Lei 11.645/08 (2008-2014). Dissertação (Mestrado em História). Pelotas: UFPel, 2017.

PEREIRA, Amilcar Araujo. O mundo negro: relações raciais e a constituição do movimento negro contemporâneo no Brasil. Rio de Janeiro: Pallas/FAPERJ, 2013.

PEREIRA, Amilcar Araujo. “A Lei 10.639/03 e o movimento negro: aspectos da luta pela 'reavaliação do papel do negro na história do Brasil"', Cadernos de História, Belo Horizonte, v.12, n. 17, p. 25-45, $2^{\circ}$ sem. 2011.

PEREIRA, Amauri Mendes. Trajetória e perspectivas do Movimento Negro Brasileiro. Belo Horizonte, MG: Nandyala, 2008.

PINTO, Regina Pahim. “A educação do negro: uma revisão bibliográfica”. Cad. Pesq., São Paulo, n. 62, p. 3-34, ago/1987.

ROMÃO, Jeruse. "Educação, instrução e alfabetização no Teatro Experimental do Negro", in.: ROMÃO, Jeruse; SECAD (Orgs.). História da Educação do Negro e outras histórias. Brasília: Ministério da Educação, Secretaria de Educação Continuada, Alfabetização e Diversidade 2005, p. 117-138.

Submetido: $20 / 05 / 2020$

Aprovado: $21 / 01 / 2021$ 